\title{
REVIEW
}

\section{Wild Rabit Management in the Iberian Peninsula: State of the Art and Future Perspectives For Iberian Lynx Conservation}

\section{Ferreira ${ }^{1,2, *} \&$ M. Delibes-Mateos ${ }^{1}$}

${ }^{1}$ Instituto de Investigación en Recursos Cinegéticos (CSIC-UCLM-JCCM), Ronda de Toledo, s/n, 13071 Ciudad Real, Spain

${ }^{2} \mathrm{CIBIO}$, Centro de Investigação em Biodiversidade e Recursos Genéticos, Universidade do Porto, 4485661, Vairão, Portugal

*Corresponding author: E-mail: catarinam.andrade@uclm.es

\begin{tabular}{|c|c|}
\hline $\begin{array}{l}\text { Keywords } \\
\text { Oryctolagus cuniculus, } \\
\text { Lynx pardinus, } \\
\text { predator-prey relationship, } \\
\text { knowledge gaps, } \\
\text { monitoring, } \\
\text { biodiversity conservation, } \\
\text { management guidelines. }\end{array}$ & $\begin{array}{l}\text { Abstract } \\
\text { The Iberian lynx, the most endangered cat in the world, is presently found } \\
\text { only in two isolated populations in southern Spain. Natural expansion } \\
\text { from these populations is limited which turns Iberian lynx reintroduction } \\
\text { programs into the only alternative to save the species from extinction. Prey } \\
\text { availability is one of the top considerations for predator reintroductions. In } \\
\text { this paper, we review the state of the art regarding wild rabbit (lynx's main } \\
\text { prey) biology, status and management in the Iberian Peninsula, and future } \\
\text { perspectives for Iberian lynx conservation. Historically, wild rabbits have } \\
\text { sharply declined in the Iberian Peninsula, mainly as a consequence of habitat } \\
\text { loss and the arrival of viral diseases. Most Iberian rabbit populations are } \\
\text { still declining so different management techniques are employed to revert } \\
\text { this scenario. Population monitoring, adjusting hunting pressure, predator } \\
\text { control, habitat management, restocking and rabbit vaccination are the most } \\
\text { frequently employed management tools. Surprisingly, strong empirical } \\
\text { evidence is still lacking to support the usefulness and impact of most of } \\
\text { these management techniques. Hence, for the success of future Iberian lynx } \\
\text { reintroductions, efforts need to be made to suppress knowledge gaps of } \\
\text { rabbit ecology and management at several levels, namely: the study of basic } \\
\text { biological parameters from natural free populations, the implementation } \\
\text { of an Iberian rabbit monitoring framework based on standardised rabbit } \\
\text { monitoring protocols (that produces systematic and periodic comparable } \\
\text { results), the study of the impact of predator control, the assessment of both } \\
\text { the costs vs. benefits of vaccinating wild rabbits against viral diseases } \\
\text { and the effectiveness of habitat management. Finally, the creation of a } \\
\text { working platform congregating researchers, hunters and game managers, } \\
\text { conservationists and further sectors involved in wild rabbit management } \\
\text { is essential for the definition of a global strategy that defends collective } \\
\text { interests and serves the ultimate goal of conserving this lagomorph. }\end{array}$ \\
\hline
\end{tabular}

\section{Introduction}

The Iberian lynx (Lynx pardinus) is the most endangered cat in the world [1]. This status is a consequence of the sharp decline the cat species has suffered over the past decades due to habitat loss, human persecution and the decline of its main prey, the wild rabbit (Oryctolagus cuniculus). Presently, Iberian lynxes are only found in Mediterranean forests and scrublands of southern Spain. Important conservation programs have been launched to preserve the last two populations, located in Doñana and eastern Sierra Morena [2]. However, these two isolated populations alone are not sufficient to support this emblematic species in the long-term. Natural expansion from these populations is highly limited by habitat fragmentation [3], which turns 
Iberian lynx reintroduction programs into the best current management options [4]. Suitable and abundant prey resources are identified by several authors as one of the top considerations for predator reintroductions [e.g. 5]. There are two key goals when considering the management of a prey species in the context of a top-order predator reintroduction: increase of numbers and expansion of distribution range to sustain viable predator populations. From this standpoint, one of the priorities of lynx reintroduction programs is inevitably the spatial expansion of wild rabbit populations by boosting its abundance.

In this paper we briefly review historical and recent wild rabbit population trends and provide management guidelines to promote the efficiency of conservation planning in the context of future Iberian lynx reintroductions.

\section{The wild rabbit - Historical and recent population trends and implications for the Iberian Lynx}

\subsection{The wild rabbit: an ideal prey for the Iberian Lynx}

The European wild rabbit is an endemic species of the Iberian Peninsula [6]. Recent investigations have highlighted the role of this lagomorph as a multifunctional keystone species in its native range [7]. For instance, rabbits act as ecosystem engineers [8], by modifying vegetation through grazing, dispersing seeds of many plant species, providing refuge for other animal species that use their warrens, among others. However, the most recognized feature is the role rabbits play as prey for more than 30 Iberian predator species, including raptors and carnivores, but also reptiles and other birds [7 and references therein]. Of all the species that eat rabbits regularly, perhaps the most emblematic one is the Iberian lynx, a flagship species for conservation in Europe [9]. A lot has been written about the dynamics of this predator-prey system in Mediterranean ecosystems, although many knowledge gaps still exist regarding this relationship.

Rabbits are undoubtedly an ideal prey for Iberian lynxes. On the one hand, rabbits have been traditionally very abundant in the Iberian Peninsula (see section 1.2) and hence highly available throughout the whole lynx distribution range. On the other hand, because of their size, rabbits are relatively easy to capture by lynxes which makes them very profitable energetically. Aldama and colleagues [10] estimated that the mean energy content of an average-sized rabbit from Doñana National Park (in this region one rabbit weighs $900 \mathrm{~g}$ on average) was approximately 1218 Kcal, of which the lynx would assimilate 885 . These authors also estimated that, excluding reproduction costs, the daily energy expenditure for an adult male lynx was around $900 \mathrm{Kcal}$ and for an adult female lynx it was near $700 \mathrm{kcal}$, which is in fact the approximate energy they obtain from one rabbit. In other words, daily prey requirements for an adult male lynx $(15 \mathrm{~kg})$ would be 1.04 adult wild rabbit per day (379 individuals/year) or $898 \mathrm{~g} /$ day, and for an adult female $(10 \mathrm{~kg}) 0.76$ adult rabbits per day (277 individuals/year) or $656 \mathrm{~g} /$ day.

The fact that rabbits constitute an ideal prey for lynxes is also supported by diet analyses from this carnivore. Table 1 shows a compilation of the studies investigating Iberian lynx diet from 1975 to 2000 . 
Table 1. Percentage of wild rabbit occurrence ( $\% \mathrm{O})$ and biomass $(\% \mathrm{~B})$ found in several Iberian lynx diet studies throughout the Iberian Peninsula from 1975 to 2000.

\begin{tabular}{|c|c|c|c|c|}
\hline Study area & Sample size & $\% \mathrm{O}$ & $\% \mathrm{~B}$ & Source \\
\hline $\begin{array}{l}\text { Doñana National Park } \\
\text { (Biological Reserve). }\end{array}$ & 1537 scats & 88.5 & 84.7 & [11] Delibes (1980) \\
\hline Western Sierra Morena. & 360 scats & 94.5 & 90.6 & [12] Gil-Sánchez et al. (2006) \\
\hline Doñana National Park. & 1339 scats & 98.7 & 96.4 & [13] Calzada (2000) \\
\hline $\begin{array}{l}\text { Sierra Morena, Montes de Toledo, } \\
\text { Sierra de Gata, Sierra de Lagunilla. }\end{array}$ & $\begin{array}{l}16 \text { gut contents, } \\
37 \text { scats }\end{array}$ & 92.4 & & [14] Delibes et al. (1975) \\
\hline Malcata. & 142 scats & 97.1 & & [15] Palma (1980) \\
\hline $\begin{array}{l}\text { Sierra Morena, Montes de Toledo, } \\
\text { Extremadura. }\end{array}$ & 40 gut contents & 85.0 & & [16] Aymerich (1982) \\
\hline Sierra Morena. & 52 scats & 96.1 & & [17] Gil-Sánchez et al. (1997) \\
\hline $\begin{array}{l}\text { Doñana National Park } \\
\text { (Coto del Rey). }\end{array}$ & 240 scats & 99.5 & 98.7 & [18] Fedriani (1997) \\
\hline
\end{tabular}

These reveal that rabbits are always the staple prey for this carnivore, occurring 85 to $99.5 \%$ in lynxes' diet or representing $84.7 \%$ to $98.7 \%$ of the total biomass consumed by lynxes. The predominance of rabbits in Iberian lynx feeding patterns has been observed not only in Doñana National Park and Sierra Morena, the two main viable lynx populations, but also in other areas where the lynx was present during the 1980's (Table 1). Interestingly, the Iberian lynx relies basically on rabbits independently of the abundance of this prey. For example, Gil-Sánchez and colleagues [12] did not find differences in lynx diet between two populations established in two different areas of Sierra Morena with high and low rabbit availability. Rabbits have sharply declined in lynxes main distribution areas (see section 1.3), and this has been cited as one of the main causes explaining the decline of the populations of this endangered carnivore [9]. Consequently, supplementary feeding programs were implemented by conservationists in an effort to sustain lynx populations. One of the best documented examples is the supplementary feeding program developed in Doñana National Park in early 2000 [19,20], where the average rabbit density was estimated to be 100 times lower $[19,20]$ than the threshold value that allows for lynx reproduction: 1 and 4.6 rabbits/ha in autumn and spring, respectively [21].

In summary, the Iberian lynx is considered a super specialist predator owing to its specialization on preying upon rabbits. Indeed, the importance of rabbits for the Iberian lynx is so high that it has been suggested that they could have played an essential role in the taxonomic separation between this Iberian carnivore and its counterpart in continental Europe, the Eurasian lynx (Lynx lynx). The Iberian lynx could have emerged as a separate species in the Pleistocene refugia of southern Spain, where it lived off wild rabbits [9], a specialization that could also have caused the difference in sizes currently observed between the two species of lynxes [9]. 1.2. The historical decline of rabbits in the Iberian Peninsula 
In ancient times, rabbits were extremely abundant in the Iberian Peninsula. This seems to be the explanation for the origin of the name Hispania, a latinization of the Phoenician expression i-shepham-im, that could mean "rabbit coast or rabbit island" [22]. There are many other examples showing the importance rabbits had during those times. For instance, according to classic Greek and Roman authors, the numbers reached by rabbits were so huge that their burrowing activity was sufficient to undermine the buildings of entire cities in the Balearic Islands [22]. In spite of this, rabbits have been massively declining since the mid- $\mathrm{XX}^{\text {th }}$ century, and their populations are presently very far from their historical abundance levels. The main factors explaining this decline are habitat loss and fragmentation, and the arrival of two viral diseases, myxomatosis during the 1950's and rabbit hemorrhagic disease (RHD) at the end of the 1980's. Other factors, such as unsustainable hunting, predation or climate change may have contributed to the long-term rabbit decline, but this has been poorly studied in the literature [but see 23].

Rabbit decline was already ongoing in the first half of the $\mathrm{XX}^{\text {th }}$ century, before the arrival of viral diseases, apparently as a consequence of habitat loss and fragmentation. In the Iberian Peninsula, as throughout the rest of Europe, economic growth and the rural exodus have contributed to changes in the agrarian structure, and led to the intensification of agriculture and livestock farming in certain areas, and to the underutilization of other vast rural areas where traditional uses ceased to be competitive [24]. Both processes favoured the appearance of large monospecific homogeneous patches of scrubland and crops, respectively, causing the loss of Mediterranean mosaics that characterized the traditional Iberian agricultural landscapes, wild rabbit's most preferred habitat [e.g. 25]. This was corroborated by Delibes-Mateos and colleagues [26] who have recently observed that the percentage of habitat variables that determined favourable areas for rabbits in Andalusia, southern Spain, during the 1960's has declined over the past decades. For example, they recorded a significant loss of sparse scrubland, likely as a consequence of rural abandonment [24], which has been suggested to have negatively affected rabbit numbers in some of the Iberian lynx distribution areas, such as Doñana National Park [27].

The decline of rabbit populations in Spain and Portugal was greatly accelerated by the arrival of myxomatosis during the 1950's. This disease, first originated in South America, where it is endemic to the native Cottontail rabbit (Syvilagus sp.), was deliberately introduced in France in 1952 by a farmer keen to eradicate rabbits from his land. The disease spread rapidly across Europe, and it was first discovered in the Iberian Peninsula in 1953 [28]. Although the information on the initial effect of the disease on rabbit populations is scarce, it probably had an immediate and catastrophic effect on rabbit numbers, as occurred in other countries, such as England or France, where the disease killed as many as $99 \%$ of rabbits when it first arrived [29]. Following the initial outbreak, mortality rates due to myxomatosis started to decline as the degree of resistance to the disease increased. Still, to this day the disease continues to play a major role in the dynamics of rabbit populations [30].

Just when populations in Spain and Portugal were recovering from myxomatosis, another viral disease greatly impacted rabbit populations again. RHD was first described in the People's Republic of China in 1984, and spread throughout Europe 
between 1987 and 1989, largely transmitted due to trade in domestic rabbits. The disease quickly expanded and appeared in the Iberian Peninsula in 1989 [e.g. 31], causing initial mortalities of 55-75\% [32,33], devastating most of rabbit populations. Five years after the arrival of RHD it was estimated that Spanish rabbit population was $50 \%$ below the abundance levels registered before the initial outbreaks of this disease [34].

\subsection{Recent rabbit trends and current status of Iberian populations}

That wild rabbit populations have sharply declined in the Iberian Peninsula from the first half of the $\mathrm{XX}^{\text {th }}$ century to the beginning of the 1990's is unquestionable. This decline was in fact responsible for the current classification of the wild rabbit as a Vulnerable and Near Threatened species in the Red List of Vertebrates of Spain and Portugal, respectively [35, 36], in the light of IUCN criteria. However, a great deal of debate and uncertainty exists among researchers and managers regarding population trends after the establishment of RHD, which has implications on the current status of rabbit populations. In a recent review of the scientific literature regarding rabbit monitoring programmes from different Iberian regions after the arrival of RHD [37, 38], Delibes-Mateos and colleagues [39] showed that in 5 out of 6 studies $(83 \%)$, based on field surveys and hunting interviews, rabbit populations were found to be declining from the early 1990's to early 2000's in Spain and Portugal, whereas only 1 study showed no clear population trends [39 and references therein]. In contrast, the two studies using hunting bags revealed slow but continuous population recovery from 1993 to 2002 [40, 41]. This contradiction could suggest that hunting bags might not truly reflect population abundances. This has also been ascertained in Portugal where a slight increase in rabbit hunting bags from 1995 to 2002 was not confirmed by field data that revealed a $27 \%$ decrease in rabbit populations at the national level over the same period [42].

In summary, most rabbit populations are still declining in different regions of the Iberian Peninsula and negative trends in rabbit numbers have been reported in centralsouthern and north-eastern Spain as well as in Portugal. As an example, the average maximum rabbit density in Doñana National Park continued to decline progressively and significantly after the establishment of RHD, and now it rarely exceeds 2 rabbits/ ha, only a third of the level seen in 1990 [43].

In spite of this general negative trend of Iberian rabbit populations, the number of Spanish locations where rabbits are regarded as agricultural pests has tremendously increased over the last years. This is motivated by the alleged damages rabbits cause to crops and by the fact that the proportion of municipalities in central Spain that currently ask for rabbit control is significantly higher than that during the 1960's [44], when rabbit numbers were supposedly higher. Overall, rabbits have been considered pests in at least $50 \%$ of the Spanish provinces over the last 5 years (R. Villafuerte, unpublished data), including both northern [e.g. Navarra, 45] and southern regions [Córdoba, 46]. Undoubtedly, in some of these areas rabbits have significantly increased their numbers, and even local population explosions have occurred. In Portugal, there is no information regarding the frequency of these requests for rabbit control although there are still areas where rabbits could potentially cause damage 
to crops. Nevertheless, it seems more likely that the high rabbit abundances (and their subsequent damage to crops) correspond to a social perception rather than to a scientifically documented reality, as observed in other regions of the world [e.g. 47]. Therefore, it is unreasonable to draw a direct association between the increase in the perception of rabbits as pests and a supposed recovery of the species in the Iberian Peninsula. Anyway, rabbit population booms, independently of their frequency, occur usually in agricultural areas highly altered by humans, being in principle unsuitable landscapes for the establishment of Iberian lynx populations. Nevertheless, it is a fact that rabbits seem to have recovered in a few natural areas like in north-eastern Spain, where $26 \%$ of the surveyed populations showed an increasing trend between 1992 and 2004 [37]. In general, positive trends have been recorded in speciesfriendly habitats, characterized by soft soils and sparse Mediterranean scrublands interspersed with good pastures and/or crops [reviewed in 39]. Additionally, rabbits seem to be recovering better in hunting estates in which various game management strategies are applied both regularly and simultaneously (e.g. low hunting pressure, predator control, habitat management, etc.) in order to increase rabbit abundance [39]. Intensively managed estates typically are favourable for rabbits but may be risky for predators, such as the Iberian lynx, because of illegal persecution [48] or human disturbance. In fact, illegal trapping was an important cause of mortality of the Iberian lynx until the 1980's which contributed to the following range contraction of the species throughout the Iberian Peninsula [49].

In conclusion, the highest rabbit abundances, and therefore the best feeding conditions for Iberian lynxes, currently occur either in agricultural areas, which do not include suitable habitats for this carnivore, or in intensively managed hunting estates, which are usually risky for predators (e.g. high levels of predator control; see section 2.2). Consequently, the conservation of the Iberian lynx requires efforts to increase rabbit densities in areas where this carnivore is still present and/or in areas where it could be reintroduced in the future. A good example is the management scheme designed to boost rabbit numbers at Valle del Río Yeguas, Sierra Morena, where the average rabbit density within the surface occupied by lynxes was 0.71 rabbits/ha in 2003 . After a strict rabbit recovery plan, which included rabbit restocking, habitat management (artificial warrens), etc., the abundance increased progressively, reaching 5.91 rabbits/ ha in 2009 [50]. The state of the art of the main management tools used to increase rabbit numbers by both conservationists and hunters is presented in the following sections.

\section{Wild rabbit management in the Iberian Peninsula}

Management actions for the wild rabbit are typically aimed at minimizing the impact of high adult and juvenile mortality (caused by viral diseases, predation, etc.) and at incrementing population productivity (warren building, supplementary food, etc.). However, the overall knowledge that supports the application of each one of these measures is not always profound even though researchers are increasingly aware of the need to fill in this gap in order to prevent the indiscriminate use of some of the more harmful management techniques. The currently available scientific literature about the wild rabbit in the Iberian Peninsula focuses mainly on the impact of viral 
diseases, myxomatosis and RHD, the effectiveness and usefulness of vaccination campaigns against these two diseases; research about habitat requirements and management and recommendations regarding sustainable harvesting; the study of phylogeography of the two recognized rabbit subspecies; and finally the association between the management of wild rabbit and its top-order predators, such as the Iberian lynx, as a means to investigate and improve the effectiveness of specific conservation actions. Nevertheless, strong empirical evidence is lacking to support the usefulness and impact of some of these actions as the basis for solid management decisions.

\subsection{Population monitoring}

Most rabbit monitoring programs developed so far in Spain and Portugal used different and unmatched methodologies [39]. This implies that it is urgent to establish a long-term programme for large-scale monitoring of rabbit abundance and trends in the Iberian Peninsula. This programme, frequently called for by scientists [39, 43], would use a standardized methodology and provide the information required to understand the extent and causes of rabbit population declines at the Iberian level. An ideal scenario would be the implementation of an Iberian network of rabbit monitoring with resources and data being shared by both countries. However, there is no consensus about the methodology that should be used to survey wild rabbit populations at such a large-scale.

Although hunting statistics can be used successfully to estimate population abundance in some cases [e.g. 51] these were not good indicators of abundance variation in Portugal, due to discrepancies observed in rabbit population trends provided by the number of harvested rabbits vs. field data over the same period of the time [42]. As a result, until they are not gathered in a more rigorous and systematic format by hunters and the Portuguese administration, hunting statistics should not be used blindly to assess rabbit status in the country. This situation is probably not exclusive to Portugal since in Spain rabbit trends estimated using hunting bags also differed from those obtained from field based-studies [39]. This inevitably implies that field data are currently the most adequate method to monitor rabbit abundance and distribution in the Iberian Peninsula.

In the light of the Wild Rabbit Recovery Programme (in Portuguese, PRECOB; Portuguese Law issue $\mathrm{n}^{\circ} 296 / 2007,8-01$ ), created by the Portuguese administration in 2005, a national wild rabbit monitoring methodology and network in the form of a project called "INCOB" was implemented in Portugal to create a standardised system of data gathering on rabbit population parameters in areas where this species plays a relevant ecological role. The methodology adopted is based on a stratified sampling of four 250-m fixed linear transects along which rabbit signs counts (latrines mainly) are performed (ideally twice a year - late spring and late autumn) distributed over $2 \times 2 \mathrm{~km}$ UTM square units. Although this method is general enough to be applied over the whole Portuguese territory, priority has been currently given to areas for potential future lynx reintroduction. In Spain, an official nationwide rabbit monitoring programme is still lacking. However, the Spanish Ministry of Environment, which is responsible for the National Inventory of Biodiversity, has targeted the wild rabbit as one of the species to be monitored in the long-term according to European legislation. 
Therefore, the Spanish Society for the Study and Conservation of Mammals is currently designing a monitoring programme, which hopefully will use a methodology comparable to that used in Portugal.

\subsection{Hunting pressure}

Nearly the entire Iberian territory can be potentially devoted to hunting purposes at some level, with important revenues coming from this sector. Around 1 million and 300.000 hunters are registered, respectively, in Spain and Portugal, and in the latter alone hunting activity accounts for 365 million euros each year [52]. Therefore, one of the most readily available tools for rabbit recovery in hunting reserves is game management. This may involve adjusting hunting pressure (hunting days, number of hunters, moratoriums) and hunting bags (number of rabbits harvested). These are adjustments hunters already do on their own initiative. For instance, Angulo and Villafuerte [53] found that in Andalusia over 75\% of hunters implemented selfimposed hunting restrictions to improve rabbit populations, especially in high rabbit abundance areas. Interestingly, in northern Spain it was shown that recovering rabbit trends were positively correlated with low hunting pressure [38]. These findings would suggest that limiting hunting activity could have positive effects on rabbit populations and that simple adjustments could be enough to stabilise population decline. Nevertheless, in some areas where hunting activity has ceased for quite some time, such as some Spanish National Parks, the abundance of rabbits is extremely low suggesting that the prohibition of hunting per se could probably be insufficient to assure rabbit recovery. In fact, Delibes-Mateos and colleagues [54] found that rabbit abundance was greater in intensively managed hunting estates compared to protected areas and other non-protected areas, probably due to policy makers not considering rabbit numbers when selecting priority areas. Similarly, Beja and colleagues [55] found that in southern Portugal wild rabbits, Iberian hares (Lepus granatensis), red-legged partridges (Alectoris rufa) and red foxes (Vulpes vulpes) were far more numerous in game estates than elsewhere. This implies that in spite of the risk of performing lynx reintroductions in hunting reserves the fact is that the scenario regarding rabbit abundance outside these areas is hardly promising. Delibes-Mateos and colleagues [54] concluded that the conservation of the Iberian lynx required efforts to increase rabbit densities in protected areas, since the best feeding conditions for this endangered predator currently occurred in hunting reserves where intensive management practices (such as predator control) are recurrent.

Additionally, Angulo and Villafuerte [53] suggested that the current governmental policy regarding the timing of hunting in south-western Europe has greatly impacted rabbit abundance and is not optimal for conserving its populations. This policy remained unchanged since at least the first half of the $\mathrm{XX}^{\text {th }}$ century, a time when it was probably established as a control measure in response to huge rabbit-induced economic losses in agriculture [53]. Therefore, a major improvement in the status of Iberian rabbit populations would be changing the timing of rabbit hunting season from late autumn/winter to late spring [53] when extraction would be optimised without compromising rabbit conservation. Not all scientists agree with this recommendation though. For example, Calvete and colleagues [56] suggested that the probability of 
over-harvesting a population results from a complex interaction between the timing of hunting, hunting selection, seasonal adult mortality, compensatory juvenile mortality and the population's turnover level. Hence future work will be required to address this issue.

\subsection{Predator control}

Predator control is a legal game management practice commonly used throughout the Iberian Peninsula. In general, this measure is aimed at controlling overabundant game predator species for damage inflicted in preys. However, most of the times there is no true knowledge on the real size of the predator population or on the extent of the damages inflicted in prey populations. Therefore, predator control poses a serious threat to biodiversity since both target and non-target species are captured. In fact, activities associated with predator control (e.g. illegal trapping) were one of the main causes of mortality of Iberian lynxes over the past decades [49]. The general decline of rabbit populations, and coincidental crashes in some other small game species, has led to conflicts between hunters and predators, potentiating an increase in poisoning and other forms of persecution that have highly impacted Iberian predators, namely raptors [57]. Currently, predator control is often associated with rabbit translocations, although Rouco and colleagues [58] suggested that it may not favour rabbit survival rate as much as the adaptation of rabbits to the release site. In general, there is little information available on the impact of this technique on target and non-target species in the Iberian Peninsula or even whether it accomplishes the final goal of favouring game species (namely wild rabbit) by limiting predation. Some evidence is provided by the works of Beja and colleagues [55] who found that game management had effectively reduced local predator abundances in intensively managed hunting reserves in southern Portugal, and Delibes-Mateos and colleagues [54] who observed that rabbit recovery was higher in areas where predator control was a recurrent management practice. However, empirical evidence is still lacking to better understand this relationship. Therefore, it is essential to develop further research on the type, intensity and impact of predator control actions and to determine the necessity of this practice and the possibility of replacing it by potentially less harmful ones that produce the same effects (e.g. habitat management to reduce predation), particularly in areas for future Iberian lynx reintroduction.

\subsection{Habitat management}

In general, habitat management techniques used to recover wild rabbit populations are considered to be effective in Mediterranean ecosystems [e.g. 27, 59]. These measures aim at increasing the availability of basic ecological resources, improving the carrying capacity of a given area. The amelioration of shelter conditions promotes a quantitative and qualitative increase of breeding sites and improves refuge cover from predators [60]. On the other hand, providing additional high quality food sources closer to shelter patches [through the establishment of pastures/crops or alternatively clearing scrubland; 59] can improve global habitat quality, strongly influencing population survival and the success of the application of further management techniques [e.g. 
restocking; 61]. In a recent review Ferreira and colleagues [62] have shown that habitat management techniques are widely used in Iberia by game managers and hunters who consider them extremely successful in recovering rabbit populations. In particular, the establishment of pastures and/or crops and the creation of water holes are thought to be the most effective management strategies for wild rabbit. Interestingly, most hunters still consider other techniques (such as translocations and predator control) to be more effective to recover this species in the wild [62]. This contrasts with the optimistic perception that these measures are effective. When investigating the magnitude of rabbit abundance changes produced by habitat management in relative (\%) and absolute terms (regression with field data), the authors found that these changes were relatively high (especially when departing from very low density populations), as was noticed in the original publications, but, in absolute terms, were hardly important. In fact, in only one study they observed that rabbit abundance shifted to a level with biological relevance, e.g. to support an Iberian lynx population during their non-reproductive period (1 rabbit/ha). Moreover, results suggested that the most employed measures were also the most expensive to apply, a possible consequence of the required implementation area. Hence, evidence seems to suggest that habitat management, although effective in increasing rabbit abundance, may actually be inefficient in reverting rabbit status in certain areas to levels of biological significance, at least following current protocols. This could be related to the lack of continuous supervision and maintenance of these measures highlighting the need for a minimum follow-up to allow for intervention and minimize their failure [59]. On the other hand, the maximization of the economic resources invested in the application of these techniques requires improving protocol designs in order to increase temporal and spatial gains.

Nevertheless, habitat management needs to be considered a priority for intervention since measures such as scrub management and crop for game species have been described as frequent activities undertaken in areas where rabbit populations seem to be recovering [54]. There is simply a stronger need to broaden the perspective that managed habitat patches are nodes embedded into the wider countryside from which impacts radiate out into the surrounding matrix. This would not only address today's conservation requirements of the species but also would slow down its decline. This is especially important in view of climate change scenarios, since alterations in the temperature and rainfall patterns might have strong effects on rabbit breeding (i.e., breeding season length, rate of pregnancies, and litter size), both directly and indirectly through changes in vegetation growth [63].

\subsection{Translocations/restocking - the potential for captive breeding in semi-extensive enclosures}

Despite efforts to rationally revert the reduction in rabbit numbers through the use of more sustainable techniques, there are still areas where endangered predators need urgent action plans and in such cases rabbit restocking may be a reliable management tool [64]. Over the past decades hunters and wildlife managers have promoted rabbit restocking so that in south-western Europe, around half a million rabbits are translocated each year from large natural populations [65]. However, the success 
of rabbit restocking is known to be generally low [e.g. 66]. Handling or capture stress and the impact of a new environment are some of the most important factors responsible for the failure of most of these experiments. Although some literature already exists on how to ameliorate transport conditions [e.g. 67], the transposition of the scientific knowledge obtained experimentally has not been fully made yet to practitioners in the field. In a review of restocking experiments in France, Letty and colleagues [65] found that it was possible to promote survival after release (up to $60-70 \%, 2$ months after release), and consequently translocation success, by choosing the best-suited individuals and by a relevant management of the habitat and wildlife in the new environment, before and after the restocking. In southwest Spain, Rouco and colleagues [68] have recently shown during an experimental restocking program that the post-release survival rate of rabbits confined to the release site for six nights was significantly higher than that of rabbits confined for three nights. The longest adaptation period after rabbit translocation minimized mortality while rabbits adapted to their new environment. Nevertheless, well planned translocation experiments and restocking are usually quite expensive measures to apply and so managers and conservationists have been in search of something less expensive and equally effective.

The establishment of semi-extensive rabbit captive breeding enclosures has become a technique widely used in conservation projects in recent years. Wildlife managers may use these systems to obtain healthy and genetically pure rabbits for soft release of individuals into the wild [69], a procedure whereby rabbits are allowed to adapt to their release site for a variable time period prior to release. This has been a growing alternative to plain restocking (immediate release of previously captured rabbits from other sites) or translocations (transference of rabbits from one site to the other with or without an adaptation period). For example, Rouco and colleagues [58] described how a comprehensive wild rabbit recovery program was designed as part of a site preparation for the future reintroduction of Iberian lynx in Córdoba province, southern Spain. Again, habitat restoration and agreements with stakeholders were performed prior to translocations using semi-extensive breeding enclosures. Also, in the Doñana Biological Reserve, López-Bao and colleagues [19] showed that the implementation of a supplementary feeding programme with domestic rabbit allowed the persistence of lynx populations in this area during long periods. Lynxes consumed most of the domestic rabbits spread over a total of 27 feeding stations, which proved to be an effective technique to sustain lynx populations when wild rabbit is scarce [19].

\subsection{Disease control}

In a recent study concerning rabbit seroprevalence against myxomatosis in the wild, García-Bocanegra and colleagues [70] have shown that the prevalence of antibodies against this disease was an average of $56.4 \%$ in 7 different sampling areas from Córdoba province, which means that the virus is widespread among the wild rabbit population in southern Spain. These authors found that the factors most associated with seropositivity to myxomatosis were season (autumn), high abundance of mosquitoes, reproductive activity, warren's insecticide treatment, RHD seropositivity, high hunting pressure and sheep presence (related to vector abundance), suggesting that some of 
these factors could be modulated in order to help design disease control programs [70]. Some of the mitigation strategies proposed by these authors include local vaccination campaigns against both viral diseases in small rabbit populations in specific areas, although other alternatives such as the implementation of educational programs for hunters, reduction of hunting bounties, and vector control are also highlighted.

Under a declining scenario, vaccination campaigns against both diseases are clearly one of the most employed management tools on the assumption of their usefulness to increase rabbit numbers [71]. However, the empirical evidence of their effectiveness is only negligible [72] and overall there seems to be no relevant relation of this tool with rabbit population change after the arrival of RHD to the Iberian Peninsula [54]. In fact, studies carried out to date have provided only inconclusive results regarding rabbits' immune response elicited by vaccination to myxomatosis and RHD [e.g. $71,74]$. This could be associated with the multitude of factors affecting the success of vaccination campaigns in the field like the general low density of wild rabbit populations, the highly variable spatial-temporal pattern exhibited by the virus [73], capture and manipulation procedures, the time at which the immunization takes place [74], or even the time when the outbreak occurs, among others [75].

In the field, the performance of "blind", non-systematic, vaccinations in low density rabbit populations may actually make them more vulnerable to extinction due to a multitude of factors [74]. In a recent study, Ferreira and colleagues [75] have experimentally shown that vaccination campaigns against myxomatosis [and also RHD, 74], as they are currently performed in the field, are generally not functional tools to conserve wild rabbit populations and hence management efforts should be directed towards restricting the use of this technique to specific situations, giving preference to the monitoring of individual immunological status and body condition, as health indicators of the population. An Iberian Wildlife Disease Surveillance Strategy could be designed in order to monitor the impact and evolution of viral diseases on rabbit populations. Cotilla and colleagues [76] recently proposed a protocol, to be included in the Spanish Wildlife Disease Surveillance Strategy, for monitoring RHD based on the prevalence of antibodies to this disease and the abundance of rabbits. These authors concluded that managers and conservationists should urgently focus their efforts on rabbit populations with low antibody prevalence against RHD, and base their strategies on tested management measures that ensure an increase in abundance allowing rabbits to overcome the suppressive impact of this disease [76].

\section{General knowledge gaps and guidelines for future rabbit research in the Iberian Peninsula}

Independently of the project motivation, conservation and/or hunting purposes, the successful managing of rabbit populations in the wild needs to be settled on a logical step-by-step approach, according to the following framework:

1. Monitoring: the establishment of baseline data for rabbit abundance and distribution inside the target area is fundamental for good conservation/management planning; without it all further measures will eventually fail due to the impossibility of timely intervention.

2. Hunting pressure: if the target area includes hunting reserves, adjustment of 
hunting bags (or the set of moratoriums if necessary) and cooperation with stakeholders and game managers are the first steps to efficiently recover rabbit populations on the site.

3. Habitat management: whether or not the target area is inside a hunting reserve, habitat viability analysis should be performed to understand the extent to which shelter, food and water are limiting rabbit populations on the site and act accordingly.

4. Captive breeding in semi-free enclosures: these experiments have provided promising results as sustainable alternatives to mere restocking operations, enhancing the long-term establishment of viable and reproductive rabbit populations on the site. Current knowledge on infra-structure specifications is already available [77] and costs of application can be written off in a few years.

5. Restocking: the application of this technique is redundant if none of the previous measures is previously implemented. Without obviating the factors limiting rabbit populations on the target area (identified through intensive population monitoring), namely those related to anthropogenic activities (such as hunting), population reinforcement would be ineffective and turn into a complete waste of resources. Nevertheless, a well planned restocking based on soft release protocols and combined with good habitat management and monitoring could be the key to recover rabbit populations in some regions and maybe the only way to secure rabbit presence in vast areas in the long-term [58].

In essence, and for the success of future Iberian Lynx reintroductions, efforts need to be made to suppress knowledge gaps of rabbit ecology at the following levels:

- Despite the abundant literature on wild rabbit biology, knowledge on basic biological parameters from natural free populations is still lacking and aspects such as the impact of predation and hunting pressure are poorly understood. Therefore, efforts need to be made to increase knowledge in some research fields, which are fundamental to correctly manage this species in the wild.

- Establishment of an Iberian rabbit monitoring framework (IRMF) that defines and implements standardised rabbit monitoring protocols and produces systematic and periodic comparable results (in pre-determined time intervals) in potential lynx reintroduction areas. An ideal scenario would be to do annual monitoring both at the high and low rabbit abundance seasons (e.g. January/ February and June/July, respectively) for the potential lynx reintroduction areas and a 2 to 3-year interval monitoring at the end of the rabbit reproductive season nationwide.

- Further investigation is needed to assess the effect of a potential change in the current timing of rabbit hunting season and evaluate whether this measure would actually provide the great benefits advocated both for wild rabbit populations and hunting activity.

- Because predator control is such an indiscriminate game management practice without full knowledge of its efficacy, experimental designs that investigate costs vs. benefits, long-term effectiveness and impact on (non) target predator and prey species need to be implemented. 
- Game managers and conservationists need to assess the costs vs. benefits of vaccinating wild rabbits against viral diseases and assess whether it would actually improve the status of the local rabbit population. In the long-term more useful efforts should be made to monitor the immunological status of the population or body condition, as sanitary indicators of the population.

- Finally, probably one of the most urgent management measures to implement is a working platform congregating researchers, hunters and game managers, conservationists and further sectors involved in wild rabbit management for the definition of a global strategy that defends collective interests and serves the goal of conserving this lagomorph without which future lynx reintroductions will be compromised.

\section{Aknowledgements}

The authors wish to thank Dr. Pedro Sarmento and one anonymous reviewer for their useful comments and suggestions on a previous version of the manuscript. M. Delibes-Mateos is currently holding a Juan de la Cierva research contract awarded by the Ministerio de Ciencia e Innovación and the European Social Fund.

\section{References}

1. Nowel, K. \& Jakson, P. 2002. Wild Cats. World Conservation Union, Gland, Switzerland.

2. Palomares, F. 2009. Iberian lynx ecology and life history. In: Vargas, A., Breintenmoser, C. \& Breintenmoser, C. (eds.), Iberian Lynx Ex situ Conservation: An Interdisciplinary Approach. Fundación Biodiversidad, Madrid, pp. 4-11.

3. Rodríguez, A. \& Delibes, M., 1992. Current range and status of the Iberian lynx (Felis pardina Temmick 1824) in Spain. Biol. Cons. 61: 189-196. doi:10.1016/0006-3207(92)91115-9

4. Calzada, J., González, L.M., Guzmán, N. \& Heredia, B. 2009. A new strategy for the conservation of the Iberian lynx. In: Vargas, A., Breintenmoser, C. \& Breintenmoser, C. (eds.), Iberian Lynx Ex situ Conservation: An Interdisciplinary Approach. Fundación Biodiversidad, Madrid, pp. 22-31.

5. Macdonald, D.W. 2009. Lessons learnt and plans laid: seven awkward questions for the future of reintroductions. In: Hayward, M.W. \& Somers, M.J. (eds), Reintroduction of Top-Order Predators. Blackwell Publishing Ltd.

6. Monnerot, M., Vigne, J.D., Biju-Duval, C., Casane, D., Callou, C., Hardy, C., Mougel, F., Soriguer, R.C., Dennebouy, N. \& Mounolou, J.C. 1994. Rabbit and man: genetic and historic approach. Genetics, Selection, Evolution 26: 167-182. doi:10.1186/1297-9686-26-S1-S167

7. Delibes-Mateos, M., Delibes, M., Ferreras, P. \& Villafuerte, R. 2008. Key role of European rabbits in the conservation of the western Mediterranean Basin Hotspot. Cons. Biol. 22: 1106-1117. doi:10.1111/j.1523-1739.2008.00993.x

8. Gálvez-Bravo, L., Belliure, J. \& Rebollo, S. 2009. European rabbits as ecosystem engineers: warrens increase density and diversity of lizards. Biodiv. Cons.18: 869-885.

9. Ferrer, M. \& Negro, J.J. 2004. The near extinction of two large European predators: Super specialists pay a prize. Cons. Biol. 18: 344-349. 
10. Aldama, J.J., Beltrán, J.F. \& Delibes, M. 1991. Energy expenditure and prey requirements of freeranging Iberian lynx in southwestern Spain. J. Wild. Manag. 55: 635-641. doi: $10.2307 / 3809512$

11. Delibes, M. 1980. El lince Ibérico. Ecología y comportamientos alimenticios en el Coto Doñana, Huelva. [Iberian Lynx. Ecology and feeding behavior in the Coto Doñana ,Huelva]. Acta Vert. 7: 1-128.

12. Gil-Sánchez, J.M., Ballesteros-Duperón, E. \& Bueno-Segura, J.F. 2006. Feeding ecology of the Iberian lynx Lynx pardinus in eastern Sierra Morena (Southern Spain). Acta Ther. 51: 85-90.

13. Calzada, J. 2000. Impacto de la depredación y selección de presa del lince Ibérico y el zorro sobre el conejo. [Impact of predation and prey selection of the Iberian lynx and fox on rabbit]. PhD Thesis. University of León.

14. Delibes, M., Palacios, F., Garzón, J. \& Castroviejo, J. 1975. Notes sur l'alimentation et la biologie du lynx pardelle, “Lynx pardina» (Temminck, 1824) en Espagne. [Notes about the diet and biology of the Iberian lynx, "Lynx pardina" (Temminck, 1824) in Spain]. Mammalia 39: 387-393. doi:10.1515/mamm.1975.39.3.387

15. Palma, L. 1980. Sobre distribuição, ecologia e conservação do lince ibérico em Portugal. [About the distribution, ecology and conservation of the Iberian lynx in Portugal]. I Reunión Iberoamericana de Zoología de Vertebrados. La Rábida, Huelva.

16. Aymerich, M. 1982. Étude comparative des régimes alimentaires du lynx pardelle (Lynx pardina Temmick, 1824) et due chat sauvage (Felis silvestris Schreber, 1777). [Comparative study of the diets of the Iberian lynx (Lynx pardina Temmick, 1824) and the wildcat (Felis silvestris Schreber, 1777)]. Mammalia 46: 515-521. doi:10.1515/mamm.1982.46.4.515

17. Gil-Sánchez, J.M., Molido Garrido, F. \& Valenzuela Serrano, G. 1997. Nota sobre la alimentación del lince Ibérico en el Parque Natural de la Sierra de Andújar (Sierra Morena Oriental). [Note about feeding ecology of the Iberian lynx in the Parque Natural de la Sierra de Andújar (Sierra Morena Oriental)]. Acta Vert. 24: 204-206.

18. Fedriani, J.M. 1997. Relaciones interespecíficas entre el lince Ibérico, Lynx pardina, el zorro, Vulpes vulpes, y el tejón, Meles meles, en el Parque Nacional de Doñana. [Interspecific relations of Iberian lynx, Lynx pardina, fox, Vulpes vulpes and badger, Meles meles, in the Parque Nacional de Doñana]. $\mathrm{PhD}$ Thesis. University of Sevilla.

19. López-Bao, J.V., Rodríguez, A. \& Palomares, F. 2008. Behavioural response of a trophic specialist, the Iberian lynx, to supplementary food: Patterns of food use and implications for conservation. Biol. Cons. 141: 1857-1867. doi:10.1016/j.biocon.2008.05.002

20. López-Bao, J.V., Palomares, F., Rodríguez, A. \& Delibes, M. 2010. Effects of food supplementation on home-range size, reproductive success, productivity and recruitment in a small population of Iberian lynx. Anim. Cons. 13: 35-42. doi:10.1111/j.1469-1795.2009.00300.x

21. Palomares, F., Delibes, M., Ferreras, P., Fedriani, J.M., Calzada, J. \& Revilla, E. 2001. Spatial ecology of the Iberian lynx and abundance of European rabbits in south western Spain. Wild. Mon. 148: 1-36.

22. García y Bellido, A. 1945. España y los españoles hace dos mil años según la geografía de Estrabón. [Spain and the Spanish two thousand years ago according to the Geografía de Estrabón]. EspasaCalpe, Madrid.

23. Tablado, Z. 2010. Patrones globales en reproducción y mortalidad de conejo de monte y su impacto en la dinámica de las poblaciones. [Global patterns of reproduction and mortality of wild rabbit and its impact on populations' dynamic]. PhD Thesis, Universidad de Sevilla, Spain. 
24. Fernández-Alés, R., Martín, A., Ortega. F., Ales, E.E., 1992. Recent changes in landscape structure and function in a Mediterranean region of SW of Spain (1950-1984). Land. Ecol. 7: 3-18. doi:10.1007/BF02573953

25. Romero-Calcerrada, R. \& Perry, G.L.W. 2004. The role of land abandonment in landscape dynamics in the SPA “Encinares del río Alberche y Cofio”, central Spain, 1984-1999. Land. Urb. Plan. 66: 217-232. doi:10.1016/S0169-2046(03)00112-9

26. Delibes-Mateos, M., Farfán, M.A., Olivero, J. \& Vargas, J.M. 2010. Land use changes as a crtical factor for long-term wild rabbit conservation in the Iberian Peninsula. Env. Cons. 37: 169-176 doi:10.1017/S0376892910000214

27. Moreno, S. \& Villafuerte, R. 1995. Traditional management of scrubland for the conservation of rabbits Oryctolagus cuniculus and their predators in Doñana National Park, Spain. Biol. Cons. 73: 81-85. doi:10.1016/0006-3207(95)90069-1

28. Muñoz, G. 1960. Anverso y reverso de la mixomatosis. [Obverse and reverse of Myxomatosis]. Dirección General de Montes, Caza y Pesca Fluvial, Madrid.

29. Fenner, F. \& Fantini, B. 1999. Biological control of vertebrate pests: The history of Myxomatosis, an experiment in evolution. CABI publishing, Oxon.

30. Cooke, B. 2008. Managing the European Rabbit: Converging interests between Australian research for rabbit control and European research for their conservation. Lagomorph Biology: Evolution, Ecology, and Conservation (ed. by P.C. Alves, N. Ferrand, and K. Hackländer), pp.317-326. Springer-Verlag, Berlin Heidelberg.

31. Villafuerte, R., Calvete, C., Blanco, J.C. \& Lucientes, J. 1995. Incidence of viral hemorrhagic disease in wild rabbit populations in Spain. Mammalia 59: 651-659.

doi:10.1515/mamm.1995.59.4.651

32. Peiró, V. \& Seva, E. 1991. Maladie hémorragique virale du lapin de garenne au sud-est de l'Espagne. [Wild rabbit's viral hemorrhagic disease in south-east Spain]. In: Proceedings of the XXth Congress of International Union of Game Biologists. IUGB, Godollo, Hungary, pp. 752-758.

33. Villafuerte, R., Calvete, C., Gortázar, C. \& Moreno, S. 1994. First epizootic of rabbit hemorrhagic disease in free living populations of Oryctolagus cuniculus at Doñana National Park, Spain. J. Wild. Dis. 30: 176-179.

34. Blanco, J.C. \& Villafuerte, R. 1993. Factores ecológicos que influyen sobre las poblaciones de conejos: incidencia de la enfermedad hemorrágica. [Ecological factors influencing rabbit populations: hemorrhagic disease incidence]. Technical report. Empresa de Transformación Agraria S.A., Madrid.

35. Villafuerte, R., \& Delibes-Mateos, M. 2007. El conejo. In: Palomo, L.J., Gisbert, J. \& Blanco, J.C. (eds.), Atlas y Libro Rojo de los Mamíferos Terrestres de España. Ministerio de MedioambienteDirección General para la Biodiversidad-SECEM, Madrid, Spain, pp. 490-491.

36. Cabral, M.J., Almeida, J., Almeida, P.R., Dellinger, T., Ferrand de Almeida, N., Oliveira, M.E., Palmeirim, J.M., Queiroz, A.I., Rogado, L. \& Santos-Reis, M. 2005. Livro Vermelho dos Vertebrados de Portugal. [Red Book of the Vertebrates of Portugal]. ICNB.

37. Calvete, C., Pelayo, E. \& Sampietro, J. 2006. Habitat factors related to wild rabbit population trends after the initial impact of rabbit haemorrhagic disease. Wild. Res. 33, 467-474. doi:10.1071/WR05107

38. Williams, D., Acevedo, P., Gortázar, C., Escudero, M.A., Labarta, J.L., Marco, J. \& Villafuerte, R. 2007. Hunting for answers: rabbit (Oryctolagus cuniculus) population trends in northeastern Spain. Eur. J. Wildl. Res. 53: 19-28.

doi:10.1007/s10344-006-0056-0 
39. Delibes-Mateos, M., Ferreras, P. \& Villafuerte, R. 2009. European rabbit population trends and associated factors: a review of the situation in the Iberian Peninsula. Mamm. Rev. 39: 124-140. doi:10.1111/j.1365-2907.2009.00140.x

40. Piorno, V. 2006. Gestión Cinegética y Conservación del Conejo de Monte. [Hunting management and conservation of wild rabbit]. PhD Thesis. Universidad de Vigo, Pontevedra, Spain.

41. Virgós, E., Cabezas-Díaz, S. \& Lozano, J. 2007. Is the wild rabbit (Oryctolagus cuniculus) a threatened species in Spain? Sociological constraints in the conservation of species. Biodiv. Cons. 16: 3489-3504.

42. Ferreira, C., Paupério, J. \& Alves, P.C. 2010. The usefulness of field data and hunting statistics in the assessment of wild rabbit (Oryctolagus cuniculus) conservation status in Portugal. Wild. Res. 37: 223-229. doi:10.1071/WR09137

43. Moreno, S., Beltrán, J.F., Cotilla, I., Kuffner, B., Laffite, R., Jordán, G., Ayala, J., Quintero, C., Jiménez, A., Castro, F. \& Villafuerte, R. 2007. Long-term decline of the European wild rabbit (Oryctolagus cuniculus) in south-western Spain. Wild. Res. 34: 652-658.

44. Ríos, C.A., Cañadilla, J., Martínez, E., Castro, F., Vargas, J.M. \& Villafuerte, R. 2007. Rescatando las fuentes de información: las solicitudes de control de conejo en España. [Recovering information sources: applications for rabbit control in Spain]. In: SECEM (ed.), Proceedings of the VIII Jornadas de la Sociedad Española para la Conservación y Estudio de los Mamíferos. SECEM, Huelva, Spain, p.156.

45. Villanúa, D., Olaiz, I., Castién, E., Artazcoz, R., Torres, J., Leránoz, I., Larumbe, J., Ardaiz, J. and Cormenzana, A. 2005. El conejo de monte (Oryctolagus cuniculus) en la Comunidad Foral de Navarra; evolución en el tiempo y riesgos asociados a su recuperación. [Wild rabbit (Oryctolagus cuniculus) in the Comunidad Foral de Navarra; time evolution and risks associated with its recovery]. In: SECEM (ed.), Proceedings of the VII Jornadas de la Sociedad Española para la Conservación y Estudio de los Mamíferos. SECEM, Valencia, Spain, p. 217.

46. Barrio, I.C., Bueno, G.C., Tortosa, F.S. 2010. Alternative food and rabbit damage in vineyards of southern Spain. Agric. Ecosyst. Environ. 138: 51-54.

47. Smith, A.T, Zahler, P. \& Hinds, L.A. 2006. Ineffective and unsustainable poisoning of native small mammals in temperate Asia: a classic case of the science-policy divide. In: McNeely, J.A., McCarthy, T.M., Smith, A.T., Olsvig-Whittaker, L. \& Wikramanayake, E.D. (eds), Conservation biology in Asia. Society for Conservation Biology and Resources Himalaya Foundation, Kathmandu. pp. 285-293.

48. Virgós, E. \& Travaini, A. 2005. Relationship between small-game hunting and carnivore diversity in central Spain. Biodiv. Cons. 14: 3475-3486.

49. Rodríguez, A. \& Delibes, M. 2004. Patterns and causes of non-mortality in the Iberian lynx during a 40-year period of range contraction. Biol. Cons. 118: 151-161. doi:10.1016/j.biocon.2003.07.018

50. Gil-Sánchez, J.M., Bueno, J., Moral, M., Rodríguez-Siles, J., Pérez, J., Lillo, S., Martín, J.M., Torralba, B., Garrote, G. \& Simón, M.A. 2009. Resultados del programa de recuperación del conejo de monte en el Valle del Río Yeguas. [Results of the wild rabbit recovery program in the Valle del Río Yeguas]. In: SECEM (ed.), Proceedings of the IX Jornadas de la Sociedad Española para la Conservación y Estudio de los Mamíferos. SECEM, Bilbao, Spain, p. 91.

51. Cattadori, I.M., Haydon, D.T., Thirgood, S.J. \& Hudson, P.J. 2003. Are indirect measures of abundance a useful index of population density? The case of red grouse harvesting. Oikos 100: 439-446. doi:10.1034/j.1600-0706.2003.12072.x 
52. Paixão, R., Godinho, S. \& Santos, P. 2009. Is the Nature 2000 Network associated with small-game bag results? Eur. J. Wildl. Res. 55: 553-559.

doi:10.1007/s10344-009-0274-3

53. Angulo, E. \& Villafuerte, R., 2003. Modelling hunting strategies for the conservation of wild rabbit populations. Biol. Cons. 115: 291-301. doi:10.1016/S0006-3207(03)00148-4

54. Delibes-Mateos, M., Ferreras, P. \& Villafuerte, R. 2008. Rabbit populations and game management: the situation after 15 years of rabbit haemorrhagic disease in central-southern Spain. Biodivers. Conserv. 17: 559-574. doi:10.1007/s10531-007-9272-5

55. Beja, P., Gordinho, L., Reino, L., Loureiro, F., Santos-Reis, M. \& Borralho, R. 2008. Predator abundance in relation to small game management in southern Portugal: conservation implications. Eur. J. Wildl. Res. 55 (3): 227-238. doi:10.1007/s10344-008-0236-1

56. Calvete, C., Angulo, E. \& Estrada, R. 2005. Conservation of European wild rabbit populations when hunting is age and sex selective. Biol. Cons. 121: 623-634. doi:10.1016/j.biocon.2004.06.013

57. Viñuela, J. \& Villafuerte, R. 2004. Predators and rabbits in Spain: a key conflict for conservation of European raptors. In: M. Thompson, D.B.M., Redpath, S., Fielding, A., Marquis, M. \& Galbraith, C.A. (eds), Birds of prey in a Changing Environment. The Stationery Office: Edinburgh, pp. 511-526.

58. Rouco, C., Morlanes, V., Marfil, C., García, J.A. \& Moreno, S. 2008. Wild rabbit recovery program when dealing with state-owner and private companies and landowners, in Hornachuelos Natural Park (Southern Spain). 3rd World Lagomorph Conference. From 17th to 19th of November, Morelia, México.

59. Ferreira, C. \& Alves, P.C. 2009. Influence of habitat management on the abundance and diet of wild rabbit (Oryctolagus cuniculus algirus) populations in Mediterranean ecosystems. Eur. J. Wildl. Res. 55: 487-496. doi:10.1007/s10344-009-0257-4

60. Villafuerte, R. 1994. Riesgos de predación y estratégias defensivas del conejo (Oryctolagus cuniculus) en el Parque Nacional de Doñana. [Predation risk and defensive strategies of the wild rabbit (Oryctolagus cuniculus) in Doñana National Park]. Ph.D. Thesis. University of Córdoba, Spain.

61. Moreno, S. \& Villafuerte, R. 1997. Translocating rabbits (Oryctolagus cuniculus): the influence of habitat quality on survival rate and population growth. In: Proceedings of the XIIth Lagomorph Workshop, Clermont-Ferrand, France, 8-11 July 1996. Gibier Faune Sauvage 14(3): 520-521.

62. Ferreira, C., Delibes-Mateos, M., Rouco, C., Rios, C.A., Díaz-Ruiz, F., Fernández de Simón, J., Ferreras, P. \& Villafuerte, R. 2009. Se puede mejorar la efectividad de la gestión del habitat para recuperar las poblaciones de conejo de monte? [Can habitat management effectiveness be improved for the recovery of wild rabbit populations?]. In: SECEM (ed.), Proceedings of the IX Jornadas de la Sociedad Española para la Conservación y Estudio de los Mamíferos. SECEM, Bilbao, Spain, p.76.

63. Tablado, Z., Revilla, E. \& Palomares, F. 2009. Breeding like rabbits: global patterns of variability and determinants of European wild rabbit reproduction. Ecography 32(2): 310-320. doi:10.1111/j.1600-0587.2008.05532.x

64. Moreno, S., Villafuerte, R., Cabezas, S. \& Lombardi, L. 2004. Wild Rabbit restocking for predator conservation in Spain. Biol. Cons. 118: 183-193.

doi:10.1016/j.biocon.2003.07.020 
65. Letty, J., Aubineau, J. \& Marchandeau, S. 2008. Improving rabbit restocking success: a review of field experiments in France. In: Alves, P.C., Ferrand, N. \& Hackländer, K. (eds), Lagomorph Biology: Evolution, Ecology and Conservation. Springer, Berlin Heidelberg New York, pp. 327-348.

66. Calvete, C., Villafuerte, R., Lucientes, J. \& Osácar, J.J. 1997. Effectiveness of traditional wild rabbit restocking in Spain. J. Zool. 241: 271-277.

doi:10.1111/j.1469-7998.1997.tb01957.x

67. Letty, J., Marchandeau, S., Clobert, J., Aubineau, J. 2000. Improving translocation success: an experimental study of anti-stress treatment and release method for European rabbits. Anim. Conserv.

3: 211-219.

doi:10.1111/j.1469-1795.2000.tb00105.x

68. Rouco, R., Ferreras, P., Castro, F. \& Villafuerte, R. 2010. A longer confinement period favors European wild rabbit (Oryctolagus cuniculus) survival during soft-releases in low-cover habitats. Eur. J. Wildl. Res. 56(3): 215-219. doi: 10.1007/s10344-009-0305-0

69. Arenas, A.J., Astorga, R.J., Garcia, I., Varo, A., Huerta, B., Carbonero, A., Cadenas, R. \& Perea, A. 2006. Captive breeding of wild rabbits: techniques and population dynamics. J. Wild. Manage. 70(6): 1801-1804. doi:10.2193/0022-541X(2006)70[1801:CBOWRT]2.0.CO;2

70. García-Bocanegra, I., Astorga, R.J., Napp, S., Casal, J., Huerta, B., Borge, C. \& Arenas, A. 2010. Myxomatosis in wild rabbit: Design of control programs in Mediterranean ecosystems. Preventive Veterinary Medicine 93: 42-50. doi:10.1016/j.prevetmed.2009.09.013

71. Cabezas, S., Calvete, C. \& Moreno, S. 2006. Vaccination success and body condition in the European wild rabbit: applications for conservation strategies. J. Wildl. Manage. 70(4):1125-1131. doi:10.2193/0022-541X(2006)70[1125:VSABCI]2.0.CO;2

72. Calvete, C., Estrada, R., Lucientes, J., Osácar, J.J. \& Villafuerte, R. 2004. Effects of vaccination against viral haemorrhagic disease (VHD) and myxomatosis on long-term mortality rates of European wild rabbits. Vet. Rec. 155: 388-92.

doi:10.1136/vr.155.13.388

73. Villafuerte, R., Jordán, G. \& Angulo, E. 2000. Biología y factores de riesgo en el conejo silvestre. [Biology and risk factors for wild rabbit]. In: Rosell J.M. (ed), Enfermedades del conejo, Tomo II: Enfermedades. [Diseases of the wild rabbit, Tome II]. Ediciones Mundi-Prensa, Barcelona, Spain, pp. 174-88.

74. Calvete, C. 2006. The use of immunization programs in wild populations: modelling effectiveness of vaccination campaigns against rabbit hemorrhagic disease. Biol. Conserv. 130: 290-300. doi:10.1016/j.biocon.2005.12.025

75. Ferreira, C., Ramírez, E., Castro, F., Ferreras, P. Alves, P.C., Redpath, S. \& Villafuerte, R. 2009. Field experimental vaccination campaigns against myxomatosis and their effectiveness in the wild. Vaccine 27: 6998-7002. doi:10.1016/j.vaccine.2009.09.075

76. Cotilla, I., Delibes-Mateos, M. Ramírez, E., Castro, F., Cooke, B.D. \& Villafuerte, R. 2010. Establishing a serological surveillance protocol for rabbit hemorrhagic disease by combining mathematical models and field data: implication for rabbit conservation. Eur. J. Wildl. Res. 56: 725-733.

77. Rouco, C. 2008. Restauración de las poblaciones de conejo de monte y mejora de la gestión para su conservación. [Restoration of wild rabbit populations and improvement of management for its conservation]. Ph.D. Thesis. University of Castilla-La Mancha, Spain. 